\title{
Brief Resilience Scale: Testing its factorial structure and invariance in Brazil*
}

\section{Breve Escala de Resiliencia: Testando su estructura e invariancia factorial en Brazil}

Recibido: 14 de junio de 2015 | Aceptado: 13 de junio de 2016

\author{
Gabriel Lins de Holanda COElHo ** \\ PAul H. P. HANEL \\ Cardiff University, United Kingdom \\ Thiago Medeiros CavalCANTI $* * *$ \\ Alessandro TeIXeIRa ReZENDE ***** \\ VALDINEY VELOSO GOUVEIA $* * * * * *$ \\ University of Paraiba, Brazil
}

doi: 10.11144/Javeriana.upsy15-2.brst

Para citar este artículo: Coelho G. L. H., Cavalcanti, T. M., Rezende, A. T., \& Gouveia, V. V. (2016). Brief Resilience Scale: Testing its factorial structure and invariance in Brazil. Universitas Psychologica, 15(2), 397-408. http://dx.doi.org/10.11144/ Javeriana.upsy15-2.brst

* Artículo de investigación científica y tecnológica. Coordination for the Improvement of Higher Education Personnel (CAPES), through Ph.D. scholarship made available to the first author.

** Ph.D. candidates in Psychology at Cardiff University. Correo: School of Psychology, Tower Building, 70 Park Place, Cardiff (United Kingdom). CF103AT. Correo electrónico: linshc@gmail.com ; hanelph@cardiff.ac.uk

**** Ph.D. candidate in Social Psychology at Federal University of Paraiba.

****** Undergraduate in Psychology at Federal University of Paraiba.

*******Full Professor in Social Psychology at Federal University of Paraiba. Departamento de Psicologia, 58.051900 Joao Pessoa, PB, Brazil. Correo electrónico: vvgouveia@gmail.com

\begin{abstract}
A B S T R A C T
Across two studies we aimed to provide evidences of validity and reliability for the Brief Resilience Scale (BRS) in Brazil. In study 1, 171 individuals participated (Age $M=21.9, S D=6.59)$ and 232 in Study 2 (Age $M=26.3$, $S D=7.06)$. Confirmatory factor analysis $(\mathrm{CFA})$ supported the predicted one-factor solution, with five items and satisfactory internal consistence ( $\alpha$ =0.76). A multi-group CFA revealed partial measurement equivalence between our and the original (USA) versions of the BRS. The BRS correlated significant with positivity and personality traits. The composite reliability was satisfying; the convergent validity, measured with the average variance extracted, was slightly below the recommendations. Overall, the results show that the measure is psychometrically suitable for research in Brazil.

Keywords

resilience; validation; measures; factorial invariance
\end{abstract}

\section{RESUMEN}

Se realizaron dos estudios buscando evidenciar la validez y confiabilidad de la Breve Escala de Resiliencia (BER) en Brasil. En el estúdio 1, 171 personas participaron $(E d a d M=21.9, S D=6.59)$ y 232 en el Estudio $2($ Edad $M$ $=26.3, \mathrm{SD}=7.06)$. El análisis factorial confirmatório (AFC) apoya la solución unifactorial, con cinco ítems y fidedignidad satisfactoria $(\alpha=0.76)$. Una AFC Multigrupo reveló la equivalencia de medición parcial entre la nuestra y la versión original (EUA) de la BER. La BER se correlaciona significativamente con positividad y rasgos de personalidad. La confiabilidad compuesta fue satisfactoria; la validez convergente, utilizando la varianza media extraída, fue ligeramente abajo de las recomendaciones. En general, los resultados muestran que la medida es psicométricamente adecuada para la investigación en Brasil.

Palabras clave

resiliencia; validación; medidas; invariancia factorial 


\section{Introduction}

Resilience can be considered as a universal phenomenon which is of high importance for the adaption of both persons and social groups (Aamaas, Keenan, Sedmak, \& Zijden, 2011). Therefore, it is not surprising that resilience is investigated in many different disciplines, such as health sciences or poverty studies. The definitions of resilience are quite similar across the disciplines. In poverty and unemployment research it was defined as "the ability to cope with situations of crisis" (Lang, 2010b, p. 86). The American Psychology Association defined resilience as "the process of adapting well in the face of adversity, trauma, tragedy, threats or significant sources of stress - such as family and relationship problems, serious health problems or workplace and financial stressors. It means 'bouncing back' from difficult experiences." (American Psychological Association, 2015)

Resilience plays an important role in various areas of our live. For example, resilience is considered to be helpful when getting unemployed: the workless who score higher in resilience are more likely to start looking for new job opportunities because they are both more solution and future oriented (Lang, 2010b). In other words, while becoming unemployed, one of the main characteristics of resilience, the ability to "bounce back" (e.g., Smith et al., 2008) becomes important. The persons who are better in recovering from their adversity are faster in starting to look for new opportunities. Therefore, the concept of resilience plays an important role in several kinds of therapies because it can help to reduce negative impact of adversities including negative chain reactions (vicious circle), and maintaining or increasing self-esteem and self-efficacy (Rutter, 1987). One important feature about resilience is that it is common in the general population; it is "made of ordinary rather than extraordinary processes" (Masten, 2001, p. 227). This implies that is possible to measure resilience with a short scale unlike more complex constructs like giftedness or creativity.

What are the factors that constitute resilience? Examples for those factors, that can be both intrapersonal and environmental (Tusaie \& Dyer, 2004), are acceptance of things that cannot be changed, creativity, future planning, happiness, humour, intelligence, meaning in life, optimism, physical attractiveness, self-regulation abilities, social skills including skills for "networking", social support, solution orientation, subjective well-being, taking responsibility, and wisdom (Lang, 2010a; Richardson, 2002; Tusaie \& Dyer, 2004). This list of factors is seen as the outcome of the "first wave" of resiliency inquiries (Richardson, 2002). The second wave focussed on the processes which enables people to attain those qualities. Finally, the third wave was a "multidisciplinary identification of motivational forces within individuals and groups and the creation of experiences that foster the activation and utilization of the forces" (Richardson, 2002, p. 308).

The guiding question in resilience research is what distinguish people who are able to overcome adversities to those who succumb their misfortune (Lang, 2010a). This makes it important to be able to measure it in an accurate way. Although resilience is considered as a complex construct which differs between several domains, as work or physical health, Smith et al. (2008) have developed a short scale to estimate the overall resilience of a person, i.e. the ability to cope with stress, being sufficient different from previous scales of resilience. This scale is unrelated to specific domains of the resilience research, such as poverty or health research, what makes it usable for a wide range of researchers.

\section{Brief Resilience Scale (BRS): Validation process}

Smith et al. (2008) argue that no resilience instrument can directly measure the construct. Many of these instruments have a different focus, like "successful stress-coping ability", "resilient coping behavior", or "central protective resources of health adjustment" (Ahern, Kiehl, Sole, \& Byers, 2006). Smith et al. (2008) developed the BRS to assess resilience in its original meaning, where, according to the authors, other resilience measures have failed to do so. 
Smith et al. (2008) aimed to develop a parsimonious instrument with only a few items, reliable, and with one dimension. The final six items were obtained from a larger list, after feedback from different researchers and undergraduate students were analyzed and integrated. The authors chose to use recoded items too, to increase the reliability.

For the validation of the measure, Smith et al. (2008) used four different samples, composed of undergraduates, cardiac rehabilitation patients, and women who either had fibromyalgia or healthy controls. The items presented loadings above 0.67 on one single factor in all samples, with Cronbach's alphas $(\alpha)$ ranging from 0.80 to 0.91 .

The BRS (Brief Resilience Scale) was found to be sufficient different from related constructs such as coping styles, social relationships, health-related outcomes and other personal characteristics (i.e., sufficient convergent and discriminant validity; Campbell \& Fiske, 1959). For example, it correlated positively with optimism and purpose in life, and negatively with pessimism and alexithymia (Smith et al., 2008).

Given the importance of the resilience in human life and the psychometric adequacy of the parsimonious BRS, we aimed to adapt this instrument to the Brazilian context, providing evidence of its factorial, convergent and discriminant validities, besides reliability and measurement equivalence. Two studies were carried out for these purposes.

\section{Study 1: Initial adaptation of the Brief Resilience Scale}

Study 1 was designed to get a preliminary overview of the structure of the items (Principal Component Analysis; PCA) and to check the reliability of the BRS. Moreover, we calculated the correlation of its scores with similar constructs.

\section{Participants}

Participants were 171 individuals, with a mean age of 21.90 (SD = 6.59), mostly female (63.7\%), heterosexual (94.2\%), of middle class $(80.2 \%)$, catholic (48\%), and single (83.6\%).

\section{Instruments}

The Brief Resilience Scale. It was developed by Smith et al. (2008) and consists of six items [e.g., It is hard for me to snap back when something bad happens; I tend to bounce back quickly after hard times]. Participants responded on a 5-point Likert scale, ranging from 1 (Strongly Disagree) to 5 (Strongly Agree). In the original paper, Cronbach's alpha ranged from 0.80 to 0.91 . The Brazilian version can be seen in the appendix.

The Positivity Scale. It was developed by Caprara et al. (2012) and has been adapted to the Brazil context by Souza, Araújo, R. Gouveia, Coelho, and V. Gouveia (2014). It consists of eight items [e.g., I generally feel confident in myself; At times, the future seems unclear to me.] and was answered on a 5-point Likert scale, ranging from 1 (Strongly Disagree) to 5 (Strongly Agree). The Brazilian version showed a Cronbach's alpha $(\alpha)$ of 0.85 .

Flourishing scale. It was developed by Diener et al. (2010), has been adapted to the Brazil context by Fonseca, Nascimento, Barbosa, Vione, and Gouveia (2015) and consists of eight items [e.g., I am optimistic about my future; I lead a purposeful and meaningful life.]. Answers are given on a 7-point Likert scale from 1 (Strongly Disagree) to 7 (Strongly Agree). The Cronbach's alpha for the Brazilian version was 0.83.

The BRS was translated by two bilingual researchers, using back-translation procedure. Next, 20 higher education students, equally distributed in gender, helped to check whether the items were clear and simple to answer. The final version can be seen in the appendix.

\section{Procedure}

The questionnaire was completed by students from a federal university. We contacted professors from different disciplines, asking for collaboration and explaining the aims of the study. Trained researchers were present during all the application. Also, they explained ethical issues of the research, including anonymity of their responses, as well the possibility to withdraw at any time without consequences. 


\section{Data Analysis}

Data analysis was done with the statistical program R (R Development Core Team, 2015). We conducted Student's $t$ test, a PCA, computed Cronbach's alpha, McDonald's omega, and Pearson correlations. For some analyses, we used psych package (Raîche, Walls, Magis, Riopel, \& Blais, 2013).

\section{Results}

First, we tested the discriminative power of the items of the BRS. We looked whether the scores differ when participants give similar answers. For that, we did a median split of the sum of all items (median $=18$ ), splitting the sample in two groups, above and below the median. T-tests were performed for each item to compare the means, revealing significant differences between the two groups $(p$ $<0.05)$ for all items. The table can be requested from the first author.

Next we tested the factorial structure of the scale, using the KMO criterion and the Bartlett's test of sphericity. The first criterion needs to be above 0.60 , while the second need to be significant (Tabachnick \& Fidel, 2013), in order to continue the analysis. Results are accordingly $[\mathrm{KMO}=0.75$ and Bartlett's test of sphericity, $\chi^{2}(15)=212.23$, $p<0.001]$.

Five criteria were used to know the number of factors to be extracted: Kaiser, Cattell, Horn, Optimal Coordinates, and Acceleration Factor. In four of the five criteria a single factor structure was found. The results are shown in Figure 1.

In line with previous findings, we decided to perform a Principal Components analysis, fixing the extraction to one factor (Table 1).

According to Table 1, item 5 did not load on the general component of resilience. Thus, we decided to eliminate it in the next analyses. The final unifactorial structure presents five items, with an eigenvalue of 2.58 , accounting for $43 \%$ of the total variance. The instrument showed good reliability results $(\omega=0.77 ; \alpha=0.76)$.

Finally, correlations were calculated between the BRS and two hypothetically associated con- structs: positivity and flourishing. We found a significant correlation of resilience with positivity $(r=0.19, p=0.006)$, but only a marginal significant correlation flourishing $(r=0.12, p$ $=0.059$ ).

\section{Partial discussion}

A PCA was performed in Study 1 to explore the structure of the BRS in Brazil. Because item 5 loaded very low (0.02) on the general component, it was deleted for all the subsequent analyses. In the original paper of Smith et al. (2008) the item 5 showed the lowest loadings in all four studies, too. One possible explanation for the low loading of item 5 is that it could be understood by Brazilians in a more general way. The expression "difficult times" ("momentos difíceis") could very well refer for Brazilians to political and societal issues, whereas the other items are understood in a more personal way. An alternative explanation is that "little trouble" ("pouco problema") is understood in a different way. Both discussed expressions are only used in item 5 . The loadings of the other items were satisfactory to good $(>|0.60|)$, supporting the proposed one-factor structure. The reliability of the instrument was satisfactory ( $\alpha$ $>$ 0.70; Kline, 2013).

As expected, we found a significant positive correlation between resilience and positivity. Both are important constructs in positive psychology. In a broader view, positivity helps to build and develop psychological resources as a basis of resilience (Youssef \& Luthans, 2007). Although the correlation was as expected positive, it was of small magnitude (Cohen, 1992), indicating that the BRS sufficiently differ from the positivity scale. Despite the correlation with flourishing was not significant, it was marginal and as expected positive, suggesting once more that the BRS presents a similar direction to another important construct of positive psychology. However, at this point the statistical analyses were essentially exploratory. Thus, we decided to carry out Study 2, focusing on more confirmatory analytical strategies. 


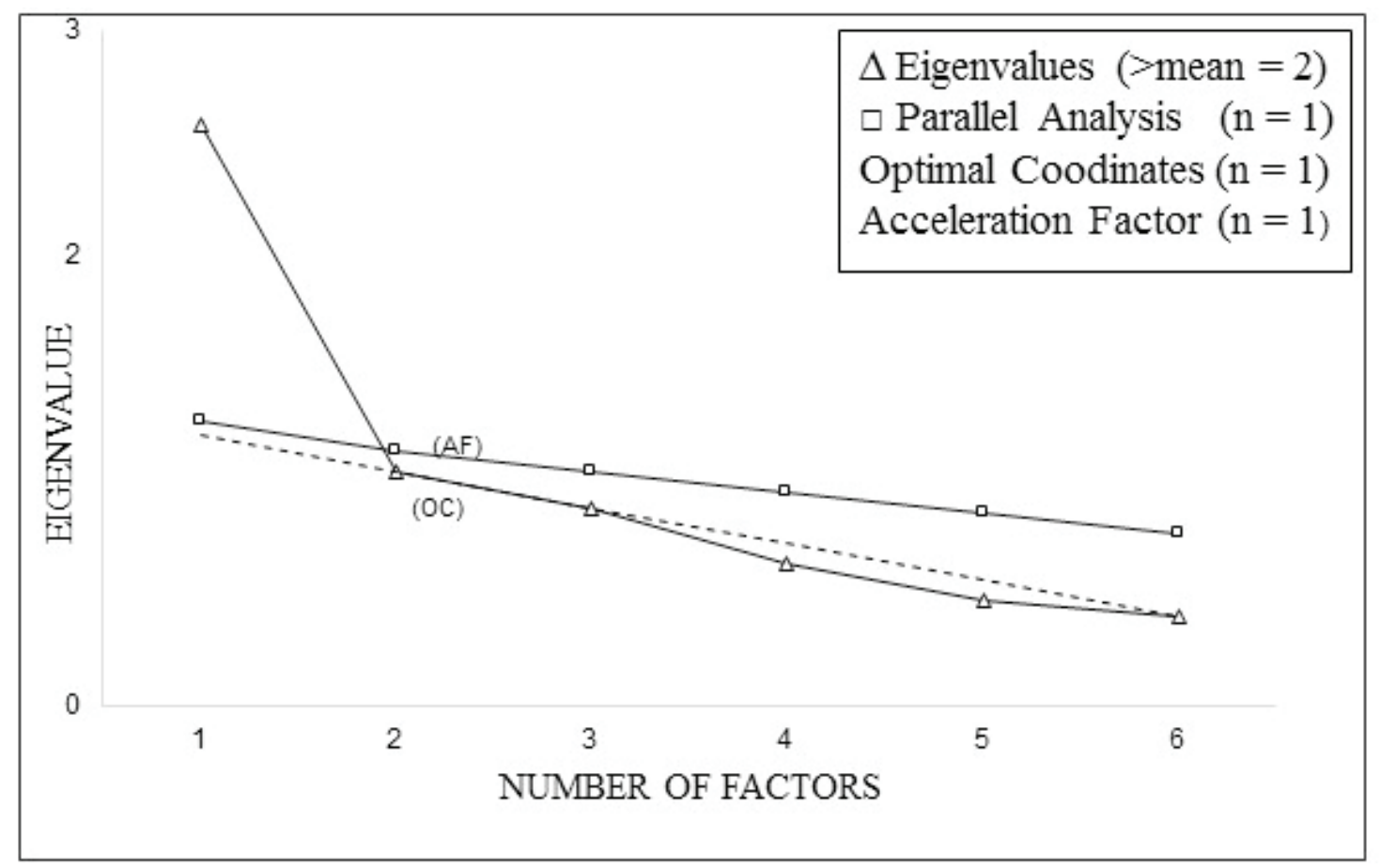

Figure 1. Distribution of the eigenvalues

Source: own work

TABLE 1

Loadings of the Brief Resilience Scale

\begin{tabular}{|c|c|c|}
\hline Item & $\frac{\text { Component }}{I}$ & $h^{2}$ \\
\hline 04. It is hard for me to snap back when something bad happens. (R) & $0.80 *$ & 0.63 \\
\hline 01. I tend to bounce back quickly after hard times. & $-0.77 *$ & 0.60 \\
\hline 06. I tend to take a long time to get over set-backs in my life. (R) & $0.76^{*}$ & 0.58 \\
\hline 02. I have a hard time making it through stressful events. (R) & $0.63^{*}$ & 0.39 \\
\hline 03. It does not take me long to recover from a stressful event. & $-0.62 *$ & 0.38 \\
\hline 05. I usually come through difficult times with little trouble. & -0.02 & 0 \\
\hline Number of Items & 5 & \\
\hline Eigenvalue & 2.58 & \\
\hline$\%$ of Variance & 43.0 & \\
\hline McDonald's omega $(\omega)$ & 0.77 & \\
\hline Cronbach's alpha $(\alpha)$ & 0.76 & \\
\hline
\end{tabular}

(R) Reversed items; * Satisfactory loadings.

Source: own work

\section{Study 2. Corroborating the one-factor structure of the Brief Resilience Scale}

The main aim of the current study was to confirm the one-factor structure of the BRS. Moreover, for the purpose of further evidence of validity, we calculated its correlations with personality traits, using the Big Five model. We expect a high negative correlation between resilience and neuroticism because the latter is more related with 
Gabriel Lins de Holanda Coelho, Paul H. P. Hanel, Thiago Medeiros Cavalcanti, Alessandro Teixeira Rezende, Valdiney Veloso Gouveia

anxiety, depressions, and nervousness, but also positive ones between resilience and openness to new experiences. This is because we assume that people who are open for new experiences focus more often on new events after experiencing stress or a setback and showing therefore higher resilience scores.

\section{Participants.}

Participants were 232 individuals, with a mean age of 26.3 (SD = 7.06), mostly female $(54.3 \%)$, heterosexual (93.5\%), single $(77.6 \%)$, from middle class $(83.2 \%)$, catholic $(53.9 \%)$, and with incomplete higher education (40.5\%).

\section{Instruments}

Participants answered first the Big Five Inventory (BFI) developed by John, Donahue, and Kentle (1991), which consists of 44 items (e.g., Is curious about many different things), which are answered on a 5-point Likert scale, ranging from 1 (Strongly Disagree) to 5 (Strongly Agree). The BFI was validated in the Brazilian context by Andrade (2008), showing Cronbach's alphas ranging from 0.68 (openness and conscientiousness) to 0.76 (extraversion). To reduce the risk of fatigue, we chose to use the shortened version of the BFI, consisting of only 20 items, four items of each dimension (Schmitt, Allik, McCrae, \& BenetMartínez, 2007). Next, participants completed the BRS and some demographic items.

\section{Procedure.}

Data collection was done online. Participants were contacted through social media and asked to complete a questionnaire at Google Docs. First, participants gave their consent to participate, the general aims of the study were explained, as well as ethical issues. The e-mail addresses of the researchers were provided, in case the participants had any concerns or questions. They took about five minutes to answer the questionnaire.

\section{Data analysis.}

All the analysis where performed in R ( $\mathrm{R}$ Development Core Team, 2011). For the confirmatory factor analysis (CFA), we used the robust maximum likelihood (ML) method, which do not require multivariate normality, through the package lavaan (Rosseel, 2012). The following fit indices were considered (Hair, Black, Babin, \& Anderson, 2015; Tabachnick \& Fidell, 2013): $\chi^{2}$ : must be nonsignificant; Comparative Fit Index (CFI): should be above 0.90; Tucker-Lewis Coefficient (TLI): values above 0.90 are good, between 0.80 and 0.90 acceptable; and Root Mean Square Error Approximation (RMSEA): values below 0.05 indicate a good fit, below 0.1 acceptable.

To allow meaningful comparisons between groups, measurements equivalence of the BRS is required. Measurement equivalence or measurement invariance is usually considered as measuring the "same concept in the same way across various subgroups of respondents" (Davidov, Meuleman, Cieciuch, Schmidt, \& Billiet, 2014, p. 58). One of the most popular and robust methods is the multigroup confirmatory factor analysis (MGCFA; Davidov et al., 2014; Vandenberg \& Lance, 2000). MGCFA is usually used for continuous variables and allows to differentiate between several hierarchically ordered levels of measurement invariance. Several levels of invariance are distinguished which need to hold before comparisons are made (Milfont \& Fischer, 2010). The first level, configural invariance, tests whether the number of factors is the same across groups. Next, metric or weak invariance needs to be established to be able to compare unstandardized regression coefficients. Finally, scalar or strong invariance needs to be established before means can be meaningfully compared. If we are unable to establish measurement equivalence, we have to assume that participants understand the items differently. In order to test for measurement equivalence, we compared the student samples used by Smith et al. (2008) in their original studies $(N=289)$ and our Brazilian sample. We considered the following parameters: $\triangle \mathrm{CFI}$ and $\triangle \mathrm{RMSEA}$, which must be equal or below 0.010 and 0.015 , respectively (Chen, 2007). 


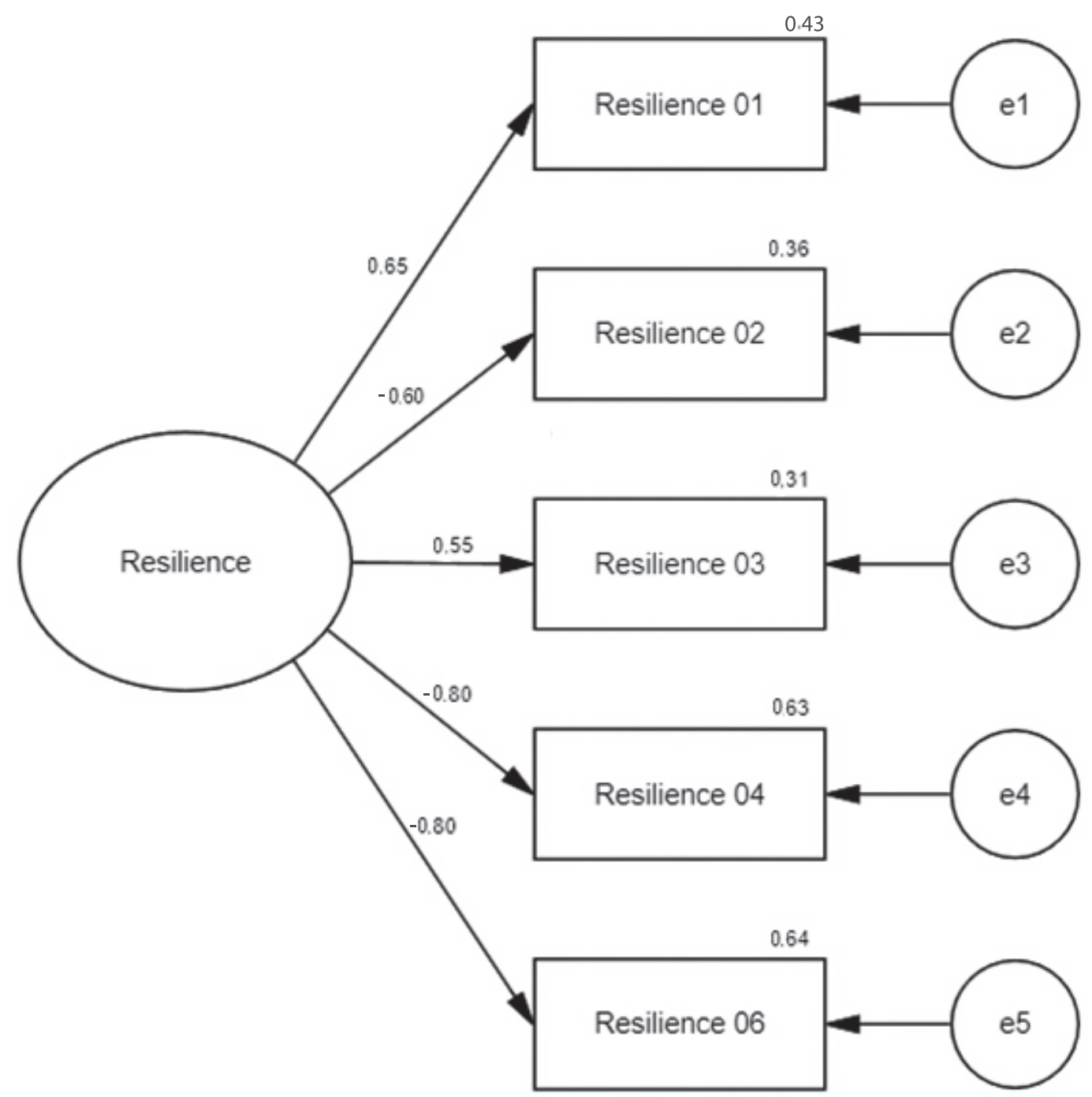

Figure 2. Factorial Structure of the Brief Resilience Scale

Source: own work

Additionally, to provide more evidences of the scale's quality, we computed the average variance extracted (AVE) and the composite reliability (CR). The AVE is the amount of average explained variance in each item by the latent variable and helps to establish convergent validity (Fornell \& Larcker, 1981). The CR checks the reliability of the measure through evaluating if the items are consistent with the latent factor (Škerlavaj \& Dimovski, 2009). For the AVE, values above 0.50 are recommended, while for the CR measure, values should be above 0.70 , while those above 0.60 are still acceptable (Fornell \& Larcker, 1981; Škerlavaj \& Dimovski, 2009).

\section{Results}

Study 2 aims to confirm the structure found in the Study 1. As reported before, one item was excluded (the original item 5), leaving five items that constitute one factor. The results provide support of a psychometrically robust scale, with acceptable to good fit indices: $\chi^{2}(5)=9.553, p>0.05$, CFI $=0.98, \mathrm{TLI}=0.96, \mathrm{RMSEA}=0.06(90 \% \mathrm{CI}=$ 
Gabriel lins de Holanda Coelho, Paul H. P. Hanel, Thiago Medeiros Cavalcanti, Alessandro Teixeira Rezende, Valdiney Veloso Gouveia

TABLE 2

Measurement equivalence of the BRS across Brazil and USA

\begin{tabular}{lcccc}
\hline \multicolumn{1}{c}{ Models } & CFI & RMSEA & $\Delta$ CFI & $\Delta$ RMSEA \\
\hline Configural invariance & 0.973 & 0.078 & & \\
\hline Metric invariance & 0.973 & 0.066 & 0 & -0.012 \\
\hline Scalar invariance & 0.966 & 0.066 & 0.007 & 0 \\
\hline
\end{tabular}

Note. $\Delta=$ differences between the current and the previous model.

Source: own work

0 - 0.112). The factorial weights ( $\lambda$, lambdas) of the items loaded between 0.65 (Item 01) and -0.80 (Item 04 and 06), that is different from zero $(\lambda \neq$ $0, z>1.96, p<0.001)$. In Figure 2 is summarized the factor structure of this measure.

Next, a multi-group CFA was performed, to test for measurement equivalence of the BRS. Following Milfont and Fischer's (2010) recommendation, we focused on the first three levels of invariance. Because we were unable to establish strong equivalence, we freed item 2 of the BRS. That is, we allowed the intercepts of this item to be different across groups. This resulted in an improved fit, but also means that the BRS is only partially invariant. The results can be seen on Table 2 . This means that mean comparisons of the BRS between Brazil and the USA must be done with care.

Finally, we also checked evidence of convergent validity and composite reliability for the BRS. We verified the convergent validity of the measure by using the average variance extracted (AVE) and the correlation of the BRS scores with the personality traits (BFI). For the AVE, the result was only marginal (0.47). However, the correlations of resilience with personality traits were as hypothesized: we observed positive correlation with extraversion $(r=0.19, p<$ 0.01 ), openness $(r=0.17, p<0.01)$, and agreeableness $(r=0.15, p<0.05)$, and a negative correlation with neuroticism $(r=-0.45, p<0.01)$. The composite reliability of the $\mathrm{BRS}$ was adequate $(\mathrm{CR}=0.81)$.

\section{Partial discussion}

Study 2 aimed to confirm the one-factor of the BRS. With five of the six original items, the structure indicated adequate psychometric properties for this instrument. A MGCFA to test the invariance between our sample and the students' samples used by Smith et al. (2008) showed partial invariances across three different models (configural, weak, and strong). Overall, our results indicate that the items of the BRS are mostly understood in Brazil as they are understood in the USA.

The composite reliability was satisfactory. Although the average variance extracted was slightly below the recommended minimum for convergent validity, we observed, as predicted, significant correlations between resilience and dimensions of the Big Five. Resilience correlated positively with agreeableness, extraversion, and openness. These traits have features that are associated with resilience, such as high levels of social interactions and trying new things (Werner \& Smith, 2001). Also, we observed a negative correlation with neuroticism. This trait is commonly associated with characteristics that are related to low resilience like negative emotions, poor coping strategies, and difficulty in controlling impulses Costa, \& McCrae (1992). Although the reported results were significant, it is important to highlight that the correlations were small (Cohen, 1992), which can be understood as a limitation of our findings. Further studies are necessary to confirm the relationship between resilience and personality.

\section{General discussion}

The aim of this research was to provide evidence of the psychometric properties of the Brief Resilience Scale (BRS) in Brazil. For that, two studies were conducted, in which we performed a PCA, CFA, and MGCFA, as well as correlations with positivity, flourishing, and personality traits. 
In Study 1, a PCA was performed and the reliability calculated. One of the six original items did not load on the first factor and was therefore deleted from the subsequent study. The reliability was found to be satisfactory (Cronbach's $\alpha$ and McDonald's $\omega$ higher than 0.70; Kline, 2013). In addition, we found positive correlations with other constructs, positivity and flourishing. As expected, both correlations were positive, but only with positivity was significant. These results shows that the BRS goes in the same direction as other similar constructs of positive psychology, but also demonstrates that the BRS is sufficiently different from these constructs.

In Study 2, a CFA, using the robust maximum likelihood (MLR) method, revealed good fit indices. These results support the structure found Study 1. Also, a MGCFA that compared the sample of this study with one sample used by Smith et al. (2008), showed that the items are similarly understood in both countries.

We still observed evidence of composite reliability and convergent validity (correlations with the factors of personality from the big five). The correlations were positive with agreeableness, extraversion, and openness, and negative with neuroticism. Similar results were found in other studies (Campbell-Sills, Cohan, \& Stein, 2006; Friborg, Barlaug, Martinussen, Rosenvinge, \& Hjemdal, 2005; Riolli, Savicki, \& Cepani, 2002; Shi, Liu, Z. Wang, \& L. Wang, 2015).

\section{Final remarks}

The aims of the studies were reached, psychometric evidence for the reliability and validity of the BRS in Brazil was found. One strength of this scale is that it is not specific for one context, and therefore can be used in many different fields (e.g., health, organizational studies, and unemployment or poverty research). Despite the good results of both studies, it is necessary to point to a few potential limitations. The samples used in the studies are not representative, limiting the generalizability. Furthermore, none of our samples was clinical. But it seems important to say that the studies tend to provide initial evidences about the instrument in Brazil, similar to the evidence found in the USA (Smith et al., 2008).

Future studies could explore the predictive validity of the BRS in various different contexts, for example with patients or unemployed people as participants. Also, it seems relevant to associate resilience with different constructs, such as human values, coping, and satisfaction with life, providing more evidences for the use of BRS and also more knowledge about resilience itself. For example, we expect that individuals guided by specific personal values (e.g., power, emotion) are more resilient and cope easier with challenges and individual problems (Gouveia, 2013).

\section{Acknowledgment}

The authors would like to thank Bruce W. Smith for sharing data from the original validation paper.

\section{References}

Aamaas, A., Keenan, W. J. F., Sedmak, C., \& Zijden, L. van der. (2011). Resilience and Unemployment: An Introduction. In A. Aamaas, W. J. F. Keenan, C. Sedmak, \& L. van der Zijden (Eds.), Resilience and Unemployment (Vol. 4, pp. 7-17). Wien: Lit Verlag.

Ahern, N. R., Kiehl, E. M., Sole, M. L., \& Byers, J. (2006). A review of instruments measuring resilience. Issues in Comprehensive Pediatric Nursing, 29(2), 103-125. http://dx.doi.org/10.1080/01460860600677643

Andrade, J. M. (2008). Evidências de validade do Inventário dos Cinco Grandes Fatores de Personalidade para o Brasil. Ph.D. thesis. Psychology Department, Brasília University, DF - Brazil.

American Psychological Association. (2015). The road to resilience. Author. Retrieved from http://www. apa.org/helpcenter/road-resilience.aspx

Author (2013). Details omitted for blind reviewing.

Campbell, D. T., \& Fiske, D. W. (1959). Convergent and discriminant validation by the multitraitmultimethod matrix. Psychological Bulletin, 56(2), 81-105. http://dx.doi.org/10.1037/h0046016 
Campbell-Sills, L., Cohan, S. L., \& Stein, M. B. (2006). Relationship of resilience to personality, coping, and psychiatric symptoms in young adults. Behaviour Research and Therapy, 44(4), 585-599. http:// dx.doi.org/10.1016/j.brat.2005.05.001

Caprara, G. V., Alessandri, G., Steca, P., Yamaguchi, S., Fukuzawa, A., Eisenberg, N.,... \& Abela, J. (2012). The Positivity Scale. Psychological Assessment, 24, 701-712.

Chen, F. F. (2007). Sensitivity of goodness of fit indexes to lack of measurement invariance. Structural Equation Modeling, 14, 464-504.

Cohen, J. (1992). A power primer. Psychological Bulletin, 112(1), 155-159.

Costa, P. T., \& McCrae, R. R. (1992). Revised NEO Personality Inventory (NEO-PI-R) and NEO FiveFactor Inventory (NEO-FFI) professional manual. Odessa, FL: Psychological Assessment Resources.

Davidov, E., Meuleman, B., Cieciuch, J., Schmidt, P., \& Billiet, J. (2014). Measurement Equivalence in Cross-National Research. Annual Review of Sociology, 40(1), 55-75. http://dx.doi.org/10.1146/ annurev-soc-071913-043137

Diener, E., Wirtz, D., Tov, W., Kim-Prieto, C., Choi, D., Oishi, S., \& Biswas-Diener, R. (2010). New Well-Being Measures: Short Scales to Assess Flourishing and Positive and Negative Feelings. Social Indicators Research, 143-156. http://dx.doi. org/10.1007/s11205-009-9493-y

Hair, J. F. J., Black, W. C., Babin, B. J., \& Anderson, R. E. (2015). Multivariate Data Analysis (7 edition). Upper Saddle River, NJ: Prentice Hall.

John, O. P., Donahue, E. M., \& Kentle, R. L. (1991). The "Big Five" Inventory EO Versions 4a and 54. Berkeley, University of California: Institute of Personality and Social Research.

Fonseca, P. N., Nascimento, B. S., Barbosa, L. H. G. M., Vione, K. C., \& Gouveia, V. V. (2015). Flourishing Scale: Evidence of Its Suitability to the Brazilian Context. Social Inquiry into Well-Being, 1(2), 33-40.

Fornell, C., \& Larcker, D. F. (1981). Evaluating Structural Equation Models with Unobservable Variables and Measurement Error. Journal of Marketing Research, 18(1), 39-50. http://dx.doi.org/10.2307/3151312

Friborg, O., Barlaug, D., Martinussen, M., Rosenvinge, J. H., \& Hjemdal, O. (2005). Resilience in relation to personality and intelligence. International Journal of Methods in Psychiatric Research, 14(1), 29-42.

Gouveia, V. V. (2013). Teoria funcionalista dos valores humanos: Fundamentos, aplicações e perspectivas. São Paulo: Casa do Psicólogo.

Kline, P. (2013). Handbook of Psychological Testing. Routledge.

Lang, D. (2010a). Defining "resilience". A working paper. Retrieved from http://www.ifz-salzburg.at/ uploads/resilience.pdf

Lang, D. (2010b). The concept of resilience as a source of insight for decent work and decent unemployment. In C. Bagusat, W. J. F. Keenan, \& C. Sedmak (Eds.), Decent work and unemployment (Vol. 3). Wien: Lit.

Masten, A. S. (2001). Ordinary magic: Resilience processes in development. American Psychologist, 56(3), 227-238. http://dx.doi.org/10.1037/0003. 066X.56.3.227

Milfont, T. L., \& Fischer, R. (2010). Testing measurement invariance across groups: Applications in cross-cultural research. International Journal of Psychological Research, 3(1), 111-121.

Raîche, G., Walls, T. A., Magis, D., Riopel, M., \& Blais, J. G. (2013). Non-Graphical Solutions for Cattell's Scree Test. Methodology, 9(1), 23-29. http://dx.doi. org/10.1027/1614-2241/a000051

R Development Core Team. (2015). R: A language and environment for statistical computing. Retrieved from https://cran.r-project.org/doc/manuals/fullrefman.pdf

Richardson, G. E. (2002). The metatheory of resilience and resiliency. Journal of Clinical Psychology, 58(3), 307-321. http://dx.doi.org/10.1002/jclp.10020

Riolli, L., Savicki, V., \& Cepani, A. (2002). Resilience in the face of catastrophe: Optimism, personality and coping in the Kosovo crisis. Journal of Applied Social Psychology, 32(8), 1604-1627. http://dx.doi. org/10.1111/j.1559-1816.2002.tb02765.x

Rosseel, Y. (2012). lavaan: An R Package for Structural Equation Modeling. Journal of Statistical Software, 48(2), 1-36.

Rutter, M. (1987). Psychosocial resilience and protective mechanisms. American Journal of Orthopsychiatry, 57(3), 316-331. http://dx.doi. org/10.1111/j.1939-0025.1987.tb03541.x 
Schmitt, D. P., Allik, J., McCrae, R. R., \& Benet-Martínez, V. (2007). The Geographic Distribution of Big Five Personality Traits Patterns and Profiles of $\mathrm{Hu}$ man Self-Description Across 56 Nations. Journal of Cross-Cultural Psychology, 38(2), 173-212. http:// dx.doi.org/10.1177/0022022106297299

Shi, M., Liu, L., Wang, Z. Y., \& Wang, L. (2015). The Mediating Role of Resilience in the Relationship between Big Five Personality and Anxiety among Chinese Medical Students: A Cross-Sectional Study. PloS One, 10(3). http://dx.doi.org/10.1371/ journal.pone.0119916

Smith, B. W., Dalen, J., Wiggins, K., Tooley, E., Christopher, P., \& Bernard, J. (2008). The brief resilience scale: Assessing the ability to bounce back. International Journal of Behavioral Medicine, 15(3), 194200. http://dx.doi.org/10.1080/10705500802222972

Souza, R. V. L. de, Araújo, R. de C. R., Gouveia, R. S. V., Coelho, G. L. de H., \& Gouveia, V. V. (2014). The Positivity Dimension of Well-Being: Adaptation and Psychometric Evidence of a Measure. Paidéia (Ribeirão Preto), 24(59), 305-312. http://dx.doi. org/10.1590/1982-43272459201404

Škerlavaj, M., \& Dimovski, V. (2009). Organizational Learning and Performance in Two National Cultu- res: A Multi-group Structural Equation Modeling Approach. In W. R. King (Ed.), Knowledge Management and Organizational Learning (pp. 321-367). Springer US. Retrieved from http://link.springer. com/chapter/10.1007/978-1-4419-0011-1_19

Tabachnick, B. G., \& Fidell, L. S. (2013). Using Multivariate Statistics (6 edition). Pearson.

Tusaie, K., \& Dyer, J. (2004). Resilience: a historical review of the construct. Holistic Nursing Practice, 18(1), 3-8; quiz 9-10.

Vandenberg, R. J., \& Lance, C. E. (2000). A review and synthesis of the measurement invariance literature: Suggestions, practices, and recommendations for organizational research. Organizational Research Methods, 3(1), 4-70. http://dx.doi. org/10.1177/109442810031002

Werner, E. E., \& Smith, R. S. (2001). Journeys from Childhood to Midlife: Risk, Resilience, and Recovery. Cornell University Press.

Youssef, C., \& Luthans, F. (2007). Positive Organizational Behavior in the Workplace: The Impact of Hope, Optimism, and Resilience. Management Department Faculty Publications. Retrieved from http://digitalcommons.unl.edu/managementfac$\mathrm{pub} / 36$ 
Gabriel lins de Holanda Coelho, Paul H. P. Hanel, Thiago Medeiros Cavalcanti, Alessandro Teixeira Rezende, Valdiney Veloso Gouveia

\section{APPENDIX: Portuguese version of BRS}

INSTRUÇÕES: Por favor, indique em que medida você concorda com cada uma das afirmações.

\begin{tabular}{ccccc}
\hline 1 & 2 & 3 & 4 & 5 \\
\hline Discordo totalmente & Discordo & $\begin{array}{c}\text { Nem concordo, nem } \\
\text { discordo }\end{array}$ & Concordo & Concordo totalmente \\
\hline
\end{tabular}

01. ____ Costumo me recuperar rapidamente de momentos difíceis.

02. Tenho dificuldade em passar por eventos estressantes.

03. Não costumo demorar para me recuperar de eventos estressantes.

04. ____É difícil me recompor quando algo ruim acontece.

05. ____ Costumo levar um longo tempo para superar os contratempos na minha vida. 